\title{
PEMETAAN PERKEMBANGAN PERHOTELAN DI PUSAT PERDAGANGAN DAN JASA KOTA SEMARANG DENGAN SISTEM INFORMASI GEOGRAFIS
}

\author{
A. Hermawan ${ }^{\text {, J.A.Syahbana }}{ }^{b}$ \\ a Universitas Diponegoro, Indonesia, email: andyhermawannn@gmail.com \\ ${ }^{b}$ Universitas Diponegoro, Indonesia, email: yoesrona@yahoo.com
}

\begin{abstract}
Article Info;
Abstract The expanded growth of the trade and services area of Peterongan - Tawang -

Received:

29 March 2015 Siliwangi (Petawangi) in Semarang City has resulted in a new growth of commercial center in revised form:

9 April 2015

Accepted:

25 April 2015

Available Online:

30 April 2015

activity within the area. Hotels as one of the potential trade and service components in the center of the area have an important role in the Semarang economy. The growth of hotels is due to the growth of activities like meeting, incentives, conference, and exhibition (MICE) as an effect of business activities in Semarang City. The share of hotels in the Petawangi area is around 70 percent of the total hotel tax in Semarang City. The purpose of this research is to identify the characteristics of the growth of hotels in the Petawangi Area during the last 3 years (2011-2014). The research has used spatio-temporal GIS and qualitative analysis, utilizing snowball sampling technique. The results show that the growth of hotels is excessive in the sense that the supply of hotel rooms exceeds the demand. The hotel growth is most intense in the urban villages of Sekayu and Pekunden. The emergence of the national government policy, which does not support the development of city hospitality through MICE,

Keywords: may result in a decrease of the hotel tax in Semarang for about 35 to 50 percent per year. To

Hotel's Mapping, GIS, be able to keep the balance between supply and demand, better cooperation between the MICE Semarang City government and the hotels managements is needed. It is especially for developing the infrastructure such as integrated inter-modal transportation for easier access to and from airport, improvement of urban facilities, city tourism development, and organizing national events to increase the declining demand of MICE. (c) 2015 GJGP UNDIP. All rights reserved.
\end{abstract}

Info Artikel;

Abstract: Adanya perkembangan Pusat Perdagangan dan Jasa Peterongan - Tawang - Siliwangi Kota Semarang yang lebih luas mengakibatkan tumbuhnya pusat-pusat kawasan komersial

Diterima:

29 Maret 2015 baru di dalamnya. Hotel sebagai salah satu komponen perdagangan dan jasa yang potensial di

Hasil Revisi : pusat perdagangan dan jasa Peterongan - Tawang - Siliwangi berperan penting sebagai penyumbang penerimaan pendapatan di Kota Semarang. Hotel berkembang akibat adanya

Hasil Revisi :
9 April 2015 perkembangan aktivitas MICE (meeting, incentives, conference, exhibition) dari efek aktivitas bisnis yang terjadi di Kota Semarang. Hotel di Kawasan Petawangi memiliki $70 \%$ dari total

Disetujui:

25 April 2015 pendapatan yang diterima dari seluruh kawasan yang ada di Kota Semarang. Tujuan dari penelitian ini dimaksudkan untuk menelusuri bagaimana perkembangan yang terjadi di sektor perhotelan di Pusat Perdagangan dan Jasa Peterongan-Tawang-Siliwangi Kota Semarang.

Publikasi On-Line: 30 April 2015 Pendekatan penelitian yang digunakan yaitu dengan metode analisis spasial temporaldan analisis kualitatif dengan menggunakan metode pengumpulan data snowball sampling. Hasil yang ditemukan bahwa saat ini pertumbuhan penyediaan perhotelan melampaui dari

Kata kunci: pertumbuhan permintaan kamar hotel. Persebaran perhotelan terpadat terjadi di Kelurahan

Pemetaan Hotel, SIG, MICE Sekayu dan Kelurahan Pekunden. Munculnya kebijakan pemerintah pusat yang tidak mendukung perkembangan perhotelan pada kota MICE mengakibatkan ancaman penurunan pendapatan hotel maupun pajak Kota Semarang 35-50\% per tahunnya. Untuk tetap dapat menjaga keseimbangan penyediaan dan permintaan maka diperlukan kerjasama antara pemerintah Kota Semarang dengan pengelola hotel untuk membangun sarana simpul transportasi bandara, pembenahan sarana - prasarana perkotaan, pembuatan daya tarik wisata dalam kota maupun penyelenggaraan event nasional untuk menyeimbangkan penurunan permintaan MICE. (C) 2015 GJGP UNDIP. All rights reserved. 


\section{PENDAHULUAN}

Pertumbuhan dan perkembangan kota diwujudkan sebagai bentuk penerjemahan dari visi dan misi kota tersebut. Visi adalah kondisi yang diinginkan pada akhir periode perencanaan yang direpresentasikan dalam sejumlah sasaran hasil pembangunan yang dicapai melalui program-program pembangunan dalam bentuk rencana kerja. Kota Semarang sebagai Ibukota Propinsi Jawa Tengah memiliki visi yang berlandaskan kondisi kota dan nilai historis yang dimilikinya. Penentuan visi ini mendasarkan pada Peraturan Daerah Nomor 6 Tahun 2010 tentang Rencana Pembangunan Jangka Panjang Daerah (RPJP) 2005 - 2025 dan penelusuran jejak historis Kota Semarang sebagai kota niaga di mana pada jaman dahulu pernah dinyatakan sebagai Kota Niaga terbesar kedua sesudah Batavia. Berdasar sejarah sebagai kota niaga tersebut dan didukung oleh analisis potensi, faktor-faktor strategis yang ada pada saat ini serta proyeksi pengembangan ke depan, maka dirumuskan visi Kota Semarang yaitu : "Terwujudnya Semarang kota perdagangan dan jasa, yang berbudaya menuju masyarakat sejahtera". Visi tersebut memiliki empat kunci pokok yakni Kota Perdagangan, Kota Jasa, Kota Berbudaya, dan Masyarakat yang Sejahtera.

Upaya yang dilakukan pemerintah dalam mengatur perkembangan Kota Semarang yang sesuai dengan visi misi serta untuk menghadapi pertumbuhan yang pesat adalah diberlakukannya pembangunan pada tingkatan bagian wilayah kota (BWK). Sesuai dengan Rencana Tata Ruang Wilayah Kota Semarang tahun 2011-2031 dikatakan bahwa BWK adalah suatu kawasan fungsional atau kawasan yang memiliki kemiripan fungsi ruang. Kota Semarang terbagi menjadi 10 bagian wilayah kota dengan masing-masing BWK memiliki fungsi kawasannya tersendiri. Sesuai dengan visi misi Kota Semarang sebagai Kota Perdagangan dan Jasa, BWK 1 merupakan pusat kawasan yang memiliki fungsi perkantoran, perdagangan, dan jasa dengan Kawsan segitiga Pandama (Pemuda, Pandaran, Gajahmada) serta Simpang Lima sebagai pusat kegiatannya atau CBD (Central Business District). BWK 1 ini mencakup Kecamatan Semarang Tengah, Semarang Selatan, dan Semarang Timur dengan luasan 2.223 Ha. Saat ini kawasan CBD Pandama telah berkembang menjadi pusat perdagangan dan jasa yang lebih luas menjadi Kawasan Petawangi (Peterongan-Tawang-Siliwangi).

Kawasan Petawangi sebagai pusat perdagangan dan jasa di Kota Semarang terus mengalami pertumbuhan yang pesat. Saat ini pemerintah Kota Semarang sedang menggalakkan investasi skala nasional dan Internasional dari penanaman modal dalam negeri maupun asing yang ditujukkan pada kawasan pusat perdagangan dan jasa Petawangi. Data yang berhasil dihimpun mencatat berbagai proyek besar perhotelan akan dibangun di kawsasan pusat kota tersebut.

\section{DATA DAN METODE}

Teori Perkembangan Kota diperlukan sebagai dasar teori yang mendasari perkembangan sektor perhotelan di Pusat Perdagangan dan Jasa Petawangi Kota Semarang. Untuk mendalami teori tentang perkembangan kota sesuai yang terjadi di pusat Kota Semarang, maka sangat diperlukan teori perkembangan kota sebagai dasar. Kota merupakan suatu kesatuan wilayah administratif yang memiliki tingkat kepadatan bangunan dan manusia yang tinggi di mana sebagian besar penduduknya bekerja bukan pada sektor pertanian. Secara lebih kompleks seperti yang dijelaskan oleh Yunus (2005:16-17) dalam sudut pandang morfologis, suatu kota dapat didefinisikan sebagai suatu daerah tertentu dengan karakteristik pemanfaatan lahan non pertanian, pemanfaatan lahan di mana sebagian besar tertutup oleh bangunan baik yang bersifat residensial maupun non residensial (secara umum tutupan bangunan / building coverage lebih besar dari komposisi vegetasi), kepadatan bangunan permukiman yang tinggi, memiliki pola jaringan jalan yang kompleks, dalam satuan permukiman yang kompak (contigous) dan relatif lebih besar dari satuan permukiman pedesaan di sekitarnya.

Berikut adalah penjelasan dari kedua bentuk perkembangan kota menurut Yunus (2005:55-):

1. Proses perkembangan spasial secara horizontal

a. Proses perkembangan spasial sentrifugal - proses perkembangan ke luar inti perkembangan.

b. Proses perkembangan spasial sentripetal - proses perkembangan kekotaan yang terjadi di bagian dalam kota (inner parts of the city)

2. Proses perkembangan spasial secara vertikal

Gejala perkembangan vertikal ini adalah proses penambahan ruang kota dengan menambahkan jumlah lantai bangunan. Perkembangan ini sering terjadi di area pusat kota (central business district) dikarenakan semakin minimnya lahan di pusat kota. 
Sektor perhotelan erat kaitannya dengan kepariwisataan. Kota Semarang sebagai kota MICE (meeting, incentives, conferencing, exhibition) sangat ditunjang dengan keberadaan layanan perhotelan untuk mendukung aktivitas MICE tersebut. Maka dari itu diperlukan perkembangan hotel yang optimal untuk mendukung aktivitas terkait pariwisata MICE di Kota Semarang.

1. Karakteristik Jasa Perhotelan

Kotler, dkk (2003) mengatakan bahwa pada dasarnya karakteristik pemasaran bidang jasa terbagi menjadi 4 hal yaitu:

a. Intangibility (tidak dapat didefinisikan)

b. Inseparability (tidak dapat dipisahkan)

Pelayanan yang tak terpisahkan berarti bahwa pengguna jasa juga merupakan bagian dari produk. Implikasi lainnya adalah pelanggan dan pekerja harus memahami sistem pelayanan jasa.

c. Variability (berbagai macam bentuk)

d. Perishability (tidak dapat disimpan)

Peraturan tentang Bagian Wilayah Kota I Semarang diatur dalam Perda Nomor 6 Tahun 2004. BWK I terdiri dari tiga kecamatan yaitu Kecamatan Semarang Tengah, Semarang Timur, dan Semarang Selatan. Fungsi kawasan ini adalah sebagai pusat kegiatan perdagangan, jasa, dan perkantoran di Kota Semarang. Luasan masing-masing kecamatan di BWK 1 sebagai berikut:

1. Kecamatan Semarang Tengah : 604,997 ha;

2. Kecamatan Semarang Timur : 770, 255 ha;

3. Kecamatan Semarang Selatan: 848,046 ha.

Sementara itu, secara administratif kawasan ini dibatasin oleh:

1. Sebelah Utara : Kecamatan Semarang Utara.

2. Sebelah Selatan : Kecamatan Gajah Mungkur dan Kecamatan Candisari.

3. Sebelah Timur : Kecamatan Gayamsari dan Kecamatan Genuk.

4. Sebelah Barat : Kecamatan Semarang Barat.

Pada kawasan BWK I Semarang ini dibagi menjadi 5 blok yang dikategorikan berdasarkan tata letak masing-masing kelurahan di dalamnya. Berikut adalah data pembagian blok BWK 1 Semarang:

Tabel 1. Pembagian Blok BWK I Kota Semarang (Bappeda Kota Semarang, 2014)

\begin{tabular}{clc}
\hline \multicolumn{1}{c}{ Kecamatan } & \multicolumn{1}{c}{ Kelurahan } & Blok \\
\hline Semarang Tengah & Pindrikan Lor, Pindrikan Kidul, Sekayu, Pandansari & 1.1 \\
& Kembangsari, Bangunharjo, Kauman, Kranggan, Purwodinatan & 1.2 \\
\cline { 2 - 3 } Semarang Timur & Miroto, Pekunden & 1.3 \\
\cline { 2 - 3 } Semarang Timur & Grabahan, Brumbungan, Jagalan, Karangkidul & 1.4 \\
\cline { 2 - 3 } Semarang Selatan & Kemijen, Rejomulyo & 2.1 \\
\cline { 2 - 3 } & Maltiharjo, Mlatibaru & 2.2 \\
\cline { 2 - 3 } Semarang Tengah & Kebonagung, Bugangan & 2.3 \\
\cline { 2 - 3 } & Karangturi, Karangtempel & 3.1 \\
\cline { 2 - 3 } & Randusari, Mugasari & 3.2 \\
\cline { 2 - 3 } & Pleburan, Wonodri & 4.1 \\
\cline { 2 - 3 } & Peterongan, Lamper Lor & 4.2 \\
\cline { 2 - 3 } & Lamper Kidul, Lamper Tengah & 5.1 \\
\hline
\end{tabular}


Untuk lebih jelas, di bawah ini adalah peta pembagian blok pada BWK I:

Gambar 1. Pembagian Blok BWK 1 (Bappeda Kota Semarang, 2014)

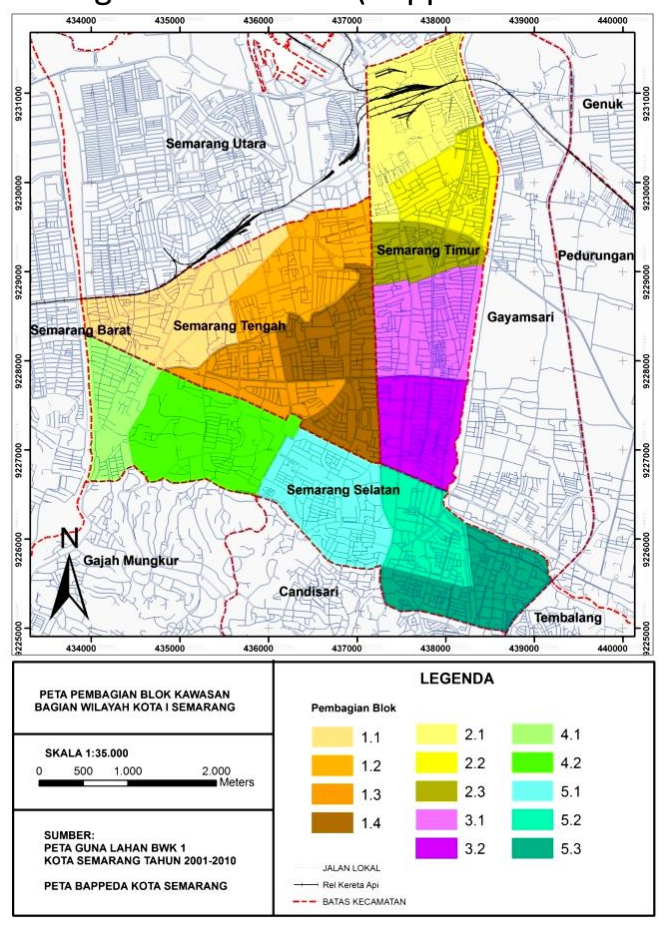

Berdasarkan data yang dihimpun dari Dinas Pariwisata Kota Semarang tahun 2014, daftar hotel berbintang di Kawasan Pusat Perdagangan dan Jasa Petawangi antara lain:

Tabel 2. Hotel Eksisting Pusat Perdagangan dan Jasa Petawangi dan Sekitanya di Kota Semarang (Dinas Pariwisata Kota Semarang, 2014)

\begin{tabular}{|c|c|c|c|}
\hline No & Nama Hotel & Alamat & Kelurahan \\
\hline 1 & Gumaya Tower Hotel & Jl Gajah Mada No 59-61 & Kelurahan Kembangsari \\
\hline 2 & Ciputra & Simpang Lima & Kelurahan Pekunden \\
\hline 3 & Novotel & Jalan Pemuda No 123 & Kelurahan Sekayu \\
\hline 4 & Crowne Plaza & Jalan Pemuda No. 116-118 & Kelurahan Sekayu \\
\hline 5 & Santika Premiere & Jalan Pandanaran No. $116-120$ & Kelurahan Pekunden \\
\hline 6 & Horison & Jl. KH Ahmad Dahlan No.2 & Kelurahan Karang Kidul \\
\hline 7 & Pandanaran & Jl Pandanaran No. 58 & Kelurahan Pekunden \\
\hline 8 & Siliwangi & Jl MGR Soegijaprnoto No. 61 & Kelurahan Pendrikan Kidul \\
\hline 9 & New Metro & JI KH Agus Salim No 2-4 & Kelurahan Puwodinatan \\
\hline 10 & Quest & Jl Plampitan No. 37-38 & Kelurahan Bangunharjo \\
\hline 11 & Dafam & Jl Imam Bonjol & Kelurahan Sekayu \\
\hline 12 & Semesta Heritage & Jl KH Wahid Hasyim No 125-127 & Kelurahan Bangunharjo \\
\hline 13 & MG Suites & Jl Petempen Malang No 294 & Kelurahan Kembangsari \\
\hline 14 & Ibis & Jl. Gajah Mada No 172 & Kelurahan Pekunden \\
\hline 15 & Holiday Inn & Jl Ahmad Yani No 145 & Kelurahan Pleburan \\
\hline 16 & Surya & Jl Imam Bonjol 28 & Kelurahan Pandan Sari \\
\hline 17 & Quirin & Jl Gajah Mada 44-52 & Kelurahan Bangunharjo \\
\hline 18 & Amaris & Jl Pemuda No 138 & Kelurahan Sekayu \\
\hline 19 & Whiz & Jl Kap. Piere Tendean No 9 & Kelurahan Sekayu \\
\hline 20 & Ibis Budget & Jl Kap Piere Tendean & Kelurahan Sekayu \\
\hline 21 & Citradream & Jl Imam Bonjol No 187 & Kelurahan Pindrikan Kidul \\
\hline 22 & Gajah Mada 100 & Jl Gajah Mada No 100 & Kelurahan Bangunharjo \\
\hline 23 & @HOM & Jl Pandanaran No 119 & Kelurahan Mugasari \\
\hline 24 & Merbabu & Jl Pemuda No 122-124 & Kelurahan Sekayu \\
\hline
\end{tabular}




\begin{tabular}{llll}
\hline No & \multicolumn{1}{c}{ Nama Hotel } & \multicolumn{1}{c}{ Alamat } & \multicolumn{1}{c}{ Kelurahan } \\
\hline $\mathbf{2 5}$ & Bali & Jl Imam Bonjol 144-148 & Kelurahan Sekayu \\
$\mathbf{2 6}$ & Aston & Jl MT Haryono No 1 & Kelurahan Purwodinatan \\
\hline
\end{tabular}

Masing-masing hotel tersebut jika ditampilkan pada area spasial, maka akan didapatkan sebaran hotel bintang seperti di bawah ini:

Gambar 2. Hotel Eksisting Pusat Perdagangan dan Jasa Petawangi (Bappeda Kota Semarang, 2014)

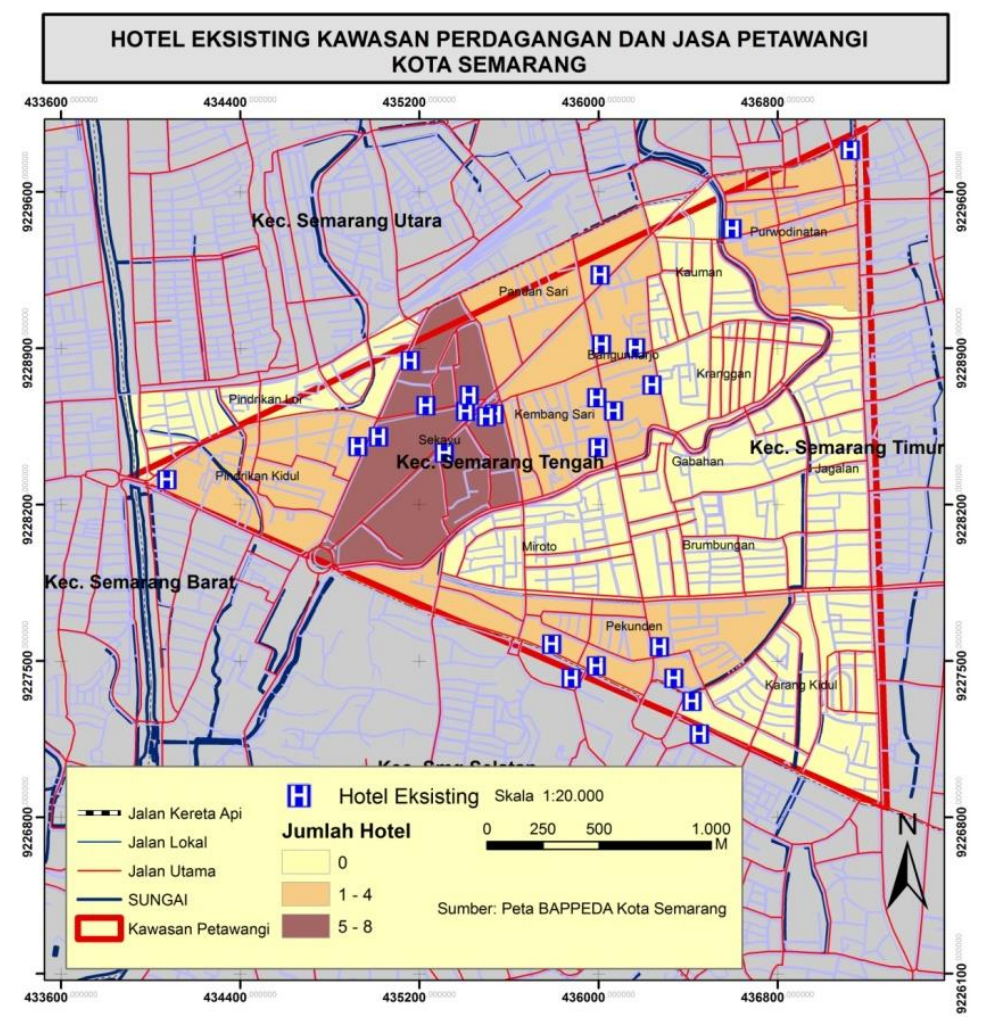

Metode GIS yang digunakan pada penelitian ini menggunakan beberapa tools analisis spasial yaitu:

1. Analisis Spasial Temporal : bertujuan untuk mengetahui seberapa besar perubahan yang terjadi pada area perdagangan jasa yang terjadi di Kawasan Petawangi pada RTRW Semarang tahun 2010 dan RTRW Kota Semarang Tahun 2011-2031.

2. Analisis Clip : bertujuan untuk membuat irisan dan mengetahui wilayah baru pengembangan dari fungsi perdagangan dan jasa di Petawangi.

3. Analisis reclass : bertujuan untuk membuat kelompok-kelompok tingkatan/kelas wilayah secara spasial dengan menggunakan data kuantitatif/sekunder yang telah diinput pada data masing-masing kelurahan.

Selain itu, pendekatan non-GIS yang digunakan dalam penelitian ini menggunakan pendekatan kualitatif dan analisis spasial temporal, untuk mengkaji perkembangan perhotelan di Pusat Perdagangan dan Jasa Peterongan - Tawang- Siliwangi Kota Semarang. Penelitian kualitatif merupakan penelitian yang menghasilkan analisis dengan menggunakan prosedur analisis yang memanfaatkan wawancara secara terbuka untuk mendapatkan informasi terkait objek yang diteliti, untuk memahami isu-isu yang dianggap sensitif dan tidak dapat diselesaikan dengan menggunakan metode penelitian kuantitatif (Moleong, 2000:6). Jenis analisis yang digunakan menggunakan metode deskriptif kualitatif. 


\section{HASIL DAN PEMBAHASAN}

Hasil temuan dan analisis diuraikan secara detail terhadap analisis - analisis yang digunakan yaitu:

3.1 Peluang Perkembangan Kawasan Perdagangan dan Jasa Petawangi

Perkembangan sektor perhotelan di kawasan Petawangi yang baru berjalan 3 tahun (2011-2014) masih membuka peluang yang terbuka lebar. Peluang perkembangan sektor perhotelan di kawasan Petawangi secara spesifik untuk saat ini masih terbuka lebar dikarenakan belum ada kajian pembatasan atau moratorium terhadap sektor tersebut.

Gambar 3. Perluasan Kawasan Perdagangan dan Jasa Petawangi (Hasil Analisis, 2014)

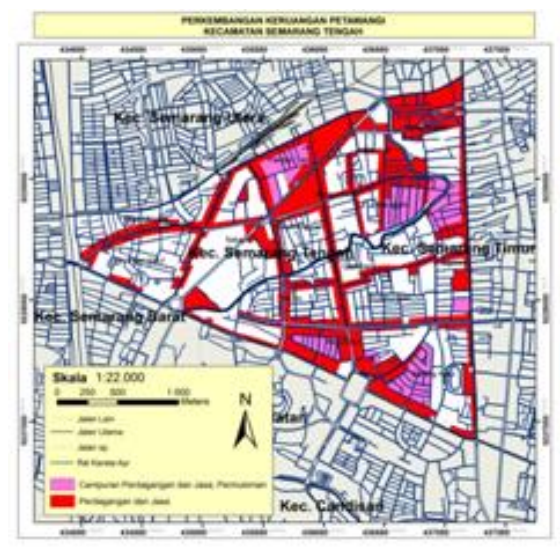

a. Tahun 2010

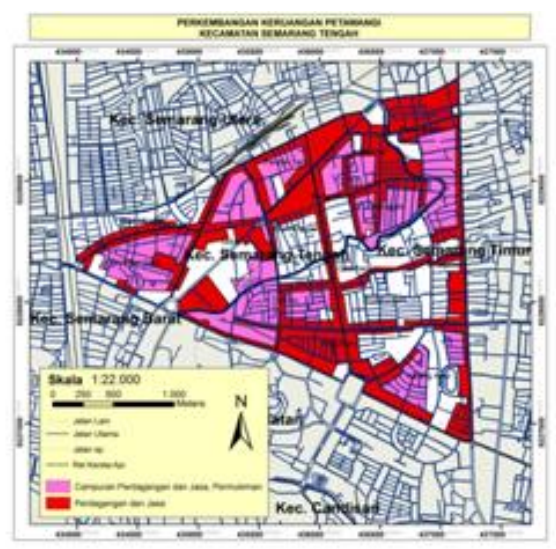

b. RTRW 2011

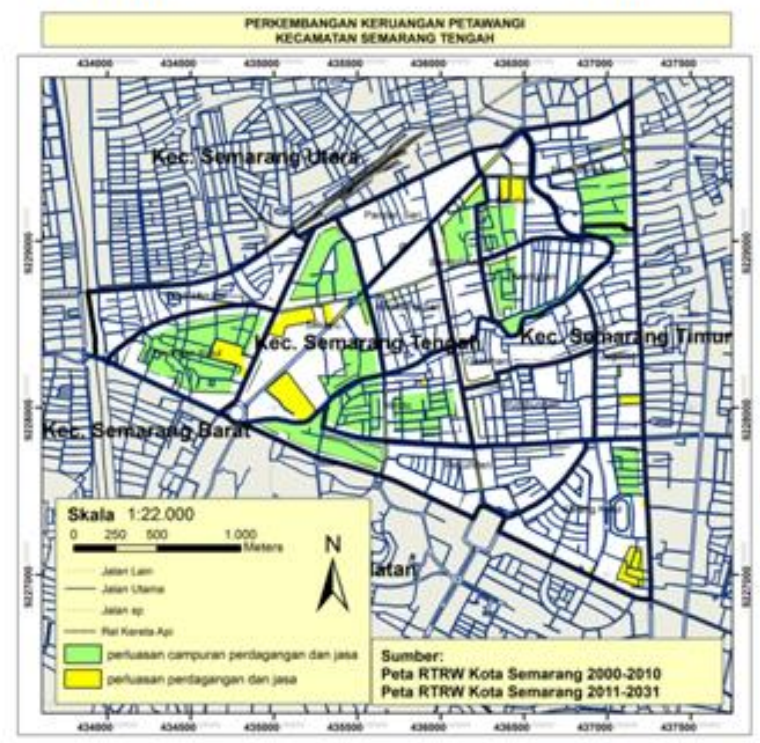

Pada peta di atas telah digambarkan bahwa terdapat perluasan yang cukup siginfikan untuk kawasan campuran perdagangan dan jasa di sekitaran Segitiga Gajah Mada-Pemuda-Pandanaran. Kawasan yang dulunya murni permukiman saat ini telah berkembang menjadi kawasan campuran permukiman dan perdagangan jasa.

Perkembangan itu memunculkan kemungkinan besar perubahan fungsi lahan yang besar terhadap kawasan permukiman terutama pada kampung kota. Beberapa kampung kota yang beralih fungsi lahan menjadi kawasan komersil perhotelan antara lain:
a. Kampung Petempen
: MG Suites Hotel dan Semarang Town Square
b. Kampung Sekayu
: Hotel Crown dan Mall Paragon extension
c. Kampung Jayenggaten
: Hotel Gumaya 


\subsection{Kebijakan Pemerintah Kota Semarang}

1. Kebijakan Perizinan

Perizinan merupakan pintu utama dari kebijakan yang diterbitkan oleh pemerintah. Keberpihakan dan kinerja pemerintah Kota Semarang akan dilihat dari bagaimana kinerja dari pengurusan perizinan. Saat ini BPPT merupakan satu-satunya badan yang mengurusi perizinan pembangunan dan penanaman modal di Kota Semarang. Dengan meningkatnya jumlah investasi maka diharapkan pertumbuhan ekonomi Kota Semarang juga meningkat dan multiplier efek dapat terjadi ke sektor lainnya.
a. Penyesuaian Perda Tata Ruang
b. Tidak ada Pembatasan Izin Perhotelan
c. Integrasi Kegiatan UMKM dengan Perhotelan
d. Pengembangan Pasar MICE
e. Pelarangan Kegiatan Instansi Pemerintah di Hotel

2. Dukungan Pemerintah Kota Semarang terhadap Perhotelan

Pemerintah Kota Semarang juga memberikan dukungan bagi sektor perhotelan yang tumnuh di Kota Semarang. Dukungan dari pemerintah Kota Semarang sangat membantu bagi keberlanjutan sektor perhotelan khususnya di Kawasan Pusat Perdagangan dan Jasa Petawangi. Penjabaran dukungan dari pemerintah terhadap sektor perhotelan antara lain Dukungan informasi perizinan dan Peningkatan infrastruktur

Gambar 4. Pengembangan Infrastruktur Petawangi (Hasil Analisis, 2014)

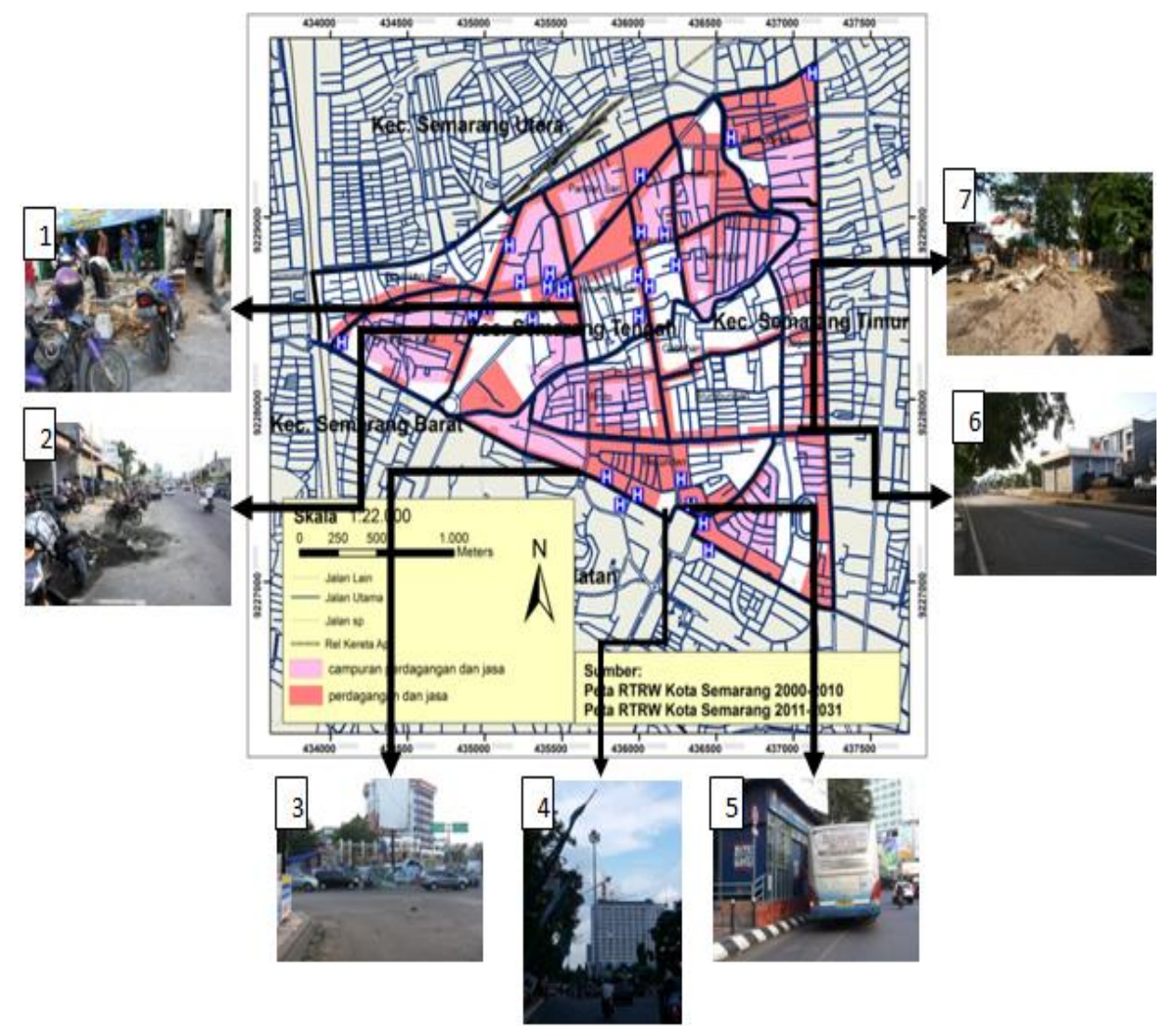

Keterangan:

1-2: perbaikan pedestrian Jalan MH Thamrin

3 : Pembangunan RTH Taman Warag Ngendhog Jl Pandanaran

4 : Penerangan Jalan DI Simpang Lima

5: Halte BRT Simpang Lima

6: Rumah Pompa Drainasi Kampung Kali

7: Pembangunan Sub Drainase Jl. Kartini 


\subsection{Analisis Perkembangan Perhotelan di Pusat Perdagangan dan Jasa Petawangi}

Sebagai sektor potensial dan juga berada di pusat kawasan Kota Semarang, pertumbuhan sektor perhotelan di Kawasan Petawangi layak mendapatkan perhatian dan kajian akademik yang mendalam untuk pengembangan yang lebih optimal dan antisiapasi terhadap permasalahan yang akan muncul di kemudian hari. Pada bahasan ini akan dijelaskan sebagai aspek yang berkaitan atas perkembangan perhotelan di Kawasan Petawangi Kota Semarang.

Merujuk pada informasi dan data yang didapatkan atas perkembangan perhotelan yang marak terjadi di tahun 2012, data instansi juga menunjukkan adanya lonjakan pengajuan pendirian hotel yang tinggi mulai tahun 2012 hingga akhir 2014 yang masuk di Kota Semarang. Rekapitulasi perizinan perhotelan yang masuk di Kota Semarang pada tiga tahun terakhir dapat dilihat pada grafik di bawah ini:

Gambar 5. Pertumbuhan Izin Pendirian Hotel DI Semarang (Hasil Analisis, 2014)

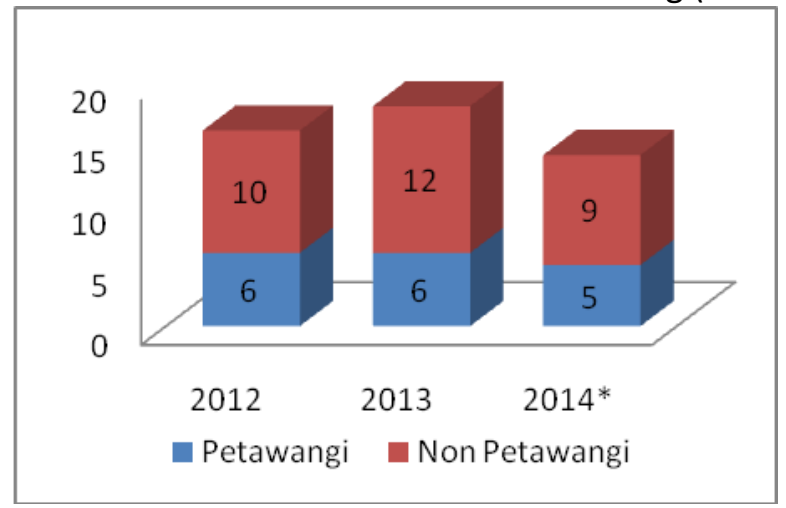

Faktor lokasi menjadi faktor terpenting bagi penentuan sukses tidaknya usaha perhotelan. Hal ini dikarenakan karena sektor perhotelan sangat berkaitan dengan layanan infastruktur lainnya seperti transportasi, perdagangan, pusat bisnis dan perkantoran. Lokasi penetuan hotel berdekatan dengan area yang strategis dan mudah aksesbillitasnya bagi pengunjung. Berdasarkan prinsip usaha yang disampaikan oleh sekretaris PHRI tentang faktor yang berpengaruh terdiri dari 4 komponen atau $4 \mathrm{P}$ yaitu: place, product promotion, price. Lokasi atau place merupakan faktor utama sebagai penentu keberhasilan usaha.

Gambar 6. Persebaran Hotel Baru dan Eksisting di Petawangi (Hasil Analisis, 2014)

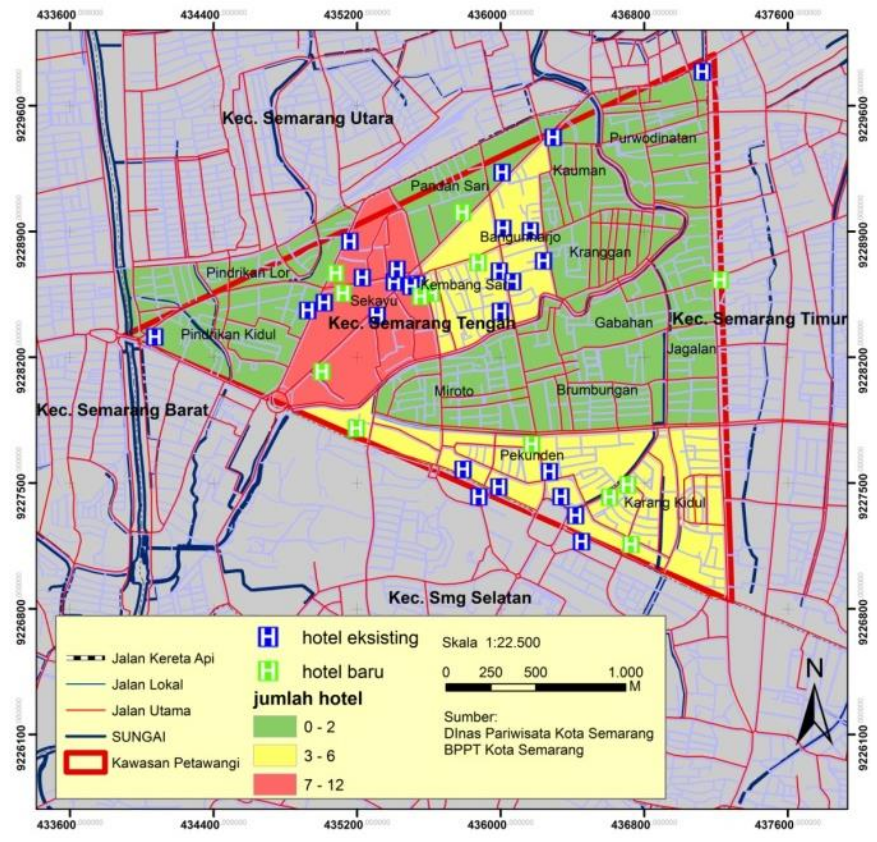


Berdasarakan kualifikasi data per masing-masing kelurahan, dikelompokkan menjadi tiga kategori berdasarkan banyaknya hotel yang ada. Didapatkan tiga klasifikasi kelurahan dengan kepadatan hotel rendah (0-2), sedang (3-6) dan tinggi (7-12) yaitu:

1. Kepadatan rendah : Pindrikan Lor, Pindrikan Kidul, Pandansari, Purwodinatan, Kauman, Kranggan, Miroto, Gabahan, Brumbungan, Jagalan.

2. Kepadatan sedang : Kembangsari, Bangunharjo, Pekunden, Karang Kidul.

3. Kepadatan tinggi : Sekayu.

Menelisik karakteristik kawasan MICE, maka lokasi pusat layanan akan menjadi magnet utama permintaan akan perhotelan MICE. Untuk melihat secara keruangan, persebaran permintaan dapat dilihat pada peta di bawah ini:

Gambar 7. Sebaran Permintaan Hotel MICE (Hasil Analisis, 2014)

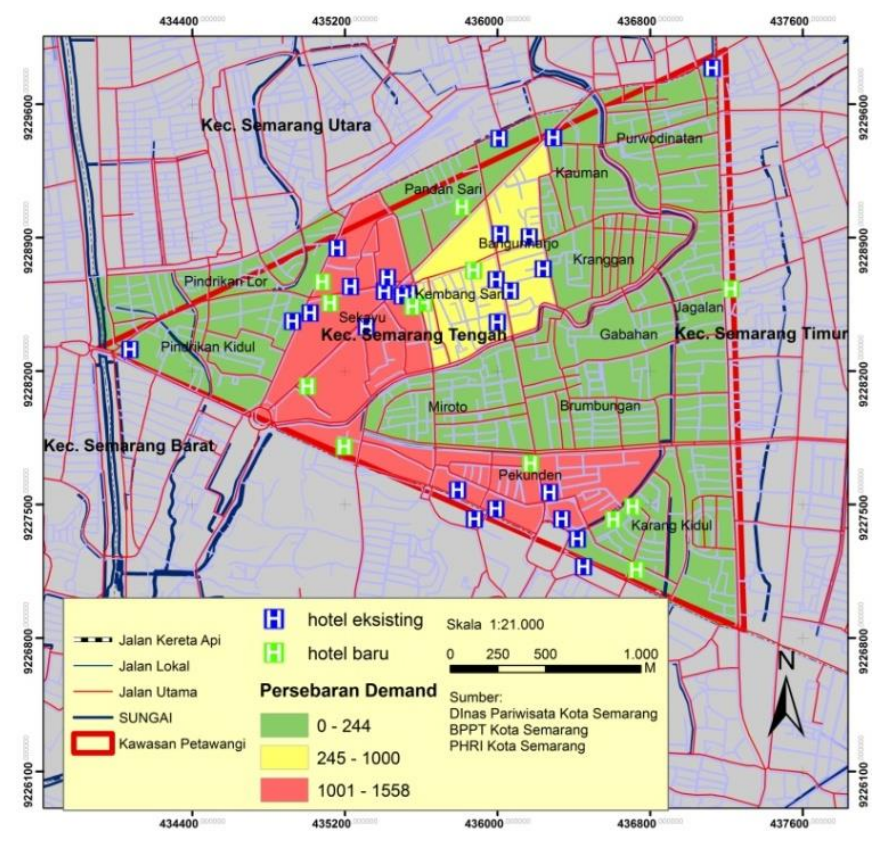

Sesuai dengan karakteristik MICE, wilayah Koridor Jalan Pandanaran - Simpang Lima dan Pemuda menjadi primadona sebagai preferensi lokasi bagi pengguna perhotelan di Kota Semarang. Adanya kemudahan akses dan ketersediaan layanan dan sektor komersial menjadi daya tarik kedua lokasi tersebut menjadi lokasi favorit bagi pengguna MICE.

\subsection{Karakteristik Pasar MICE}

1. Pasar MICE Kota Semarang

Saat ini sektor perhotelan tengah berkembang untuk mendukung sektor basis Kota Semarang dengan pengembangan htel lama dan baru yang mendukung kegiatan MICE. Untuk saat ini fasilitas yang disediakan oleh Pemerintah Kota Semarang belum mampu menampung segala jenis aktivitas bisnis dan pertemuan yang diadakan di Semarang.

2. Pengguna Kegiatan MICE Kota Semarang

Menurut cuplikan informasi wawancara menunjukkan bahwa pangsa pasar pengunjung dari Kota Semarang bukan berasal dari pendatang perorangan, hal ini kembali lagi terkait pada posisi Kota Semarang yang bukan merupakan kota yang dikunjungi untuk tujuan wisata seperti di Jogja maupun Bali. Hampir semua kedatangan di Kota Semarang memiliki motovasi pekerjaan dan bisnis yang berasal dari pemeritah pusat dan pihak swasta. Untuk melihat seberapa besar porsi untuk masing-masing pengguna MICE, dapat dilihat pada tabel di bawah ini. 
Tabel 3. Presentase Penggunaan MICE Petawangi (Hasil Analisis, 2014)

\begin{tabular}{lcc}
\hline \multirow{2}{*}{ Hotel } & \multicolumn{2}{c}{ Pengguna } \\
\cline { 2 - 3 } Metro & pemerintah & swasta \\
Grasia & 30 & 60 \\
Quest & 35 & 35 \\
Santika Premiere & 55 & 45 \\
Pandanaran & 30 & 60 \\
Novotel & 40 & 50 \\
Horison & 55 & 35 \\
rata-rata & 40 & 30 \\
Total & $\mathbf{4 0 , 7 1 4}$ & $\mathbf{4 5}$ \\
\hline
\end{tabular}

Data di atas menunjukkan bahwa pasar MICE merupakan pasar yang potensial untuk pengembangan perekonomian di Kota Semarang. Total dari hotel yang di survei menunjuukan bahwa pangsa pasar MICE untuk swasta lebih tinggi 4-5\% dari pangsa pasar MICE Pemerintah. Hal ini bukan dikarenakan karena jumlah ketersediaan pasar dari pemerintah yang lebih rendah dibanding swasta. Beberapa hotel memang membatasi kuota untuk pemerintah dikarenakan:

i. Pembayaran menggunakan LS: Tidak dibayar secara langsung

ii. Antisipasi dari pelarangan yang dilakukan oleh pemerintah pusat

3.5 Permasalahan terkait Perkembangan Sektor Perhotelan di Pusat Perdagangan dan Jasa Petawangi Semarang

1. Permasalahan Sudut Pandang Pemerintah

Permasalalahan atas perkembangan hotel ari sudut pemerintah lebih ditekankan kepada pelayanan dan kinerja dari perhotelan. Permasalahan dilihat dari seberapa besar efek yang dimunculkan atas aktivitas perhotelan yang muncul dan menggangu palayanan publik ataupun mengurangi kualitas lingkungan. Permasalahan yang diungkapkan oleh pemerintah antara lain:

a. Kurangnya ketersediaan parkir

b. Berkurangnya kualitas lingkungan

c. Kurangnya ruang terbuka hijau

2. Permasalahan Sudut Pandang Pelaku Usaha

Di sisi lain, pelaku usaha melihat permasalahan yang terjadi dari aspek peluang usaha yang kian sulit dengan persaingan yang semakin ketat. Maka menurut pelaku usaha, permasalahan yang muncul saat ini antara lain:

a. Pelarangan kegiatan instansi pemerintah di hotel.

Berdasarkan data dari PHRI Kota semarang dapat disimpulkan bahwa terjadi penurunan yang signifikan terhadap ketidakberimbangan supply dan demand karena pelarangan kegiatan perhotelan terhadap pegawai negeri. Penurunan terjadi dari tahun 2013 hingga awal tahun 2015 di mana jumlah hotel justru makin meningkat. Penurunan terjadi hingga 33,6\% antara tahun 2013 hingga 2015. Untuk lebih jelasnya dapat dilihat pada table berikut ini.

Tabel 4. Perhitungan Tingkat Hunian Hotel Petawangi (Sumber: PHRI Kota Semarang)

\begin{tabular}{ccccccc}
\hline \multicolumn{7}{c}{ Perkembangan Perhotelan Kawasan Petawangi } \\
\hline Tahun & Jumlah Hotel & R. Available & R. Sold & Occp & ARR & Total Room Rev \\
$\mathbf{2 0 1 3}$ & 15 & 816.473 & 560.942 & 70 & 496.035 & $\mathbf{2 8 5 . 8 3 4 . 6 1 7 . 4 6 3}$ \\
$\mathbf{2 0 1 4}$ & 17 & 829.159 & 538.429 & 66 & 376.536 & $\mathbf{2 0 7 . 7 3 6 . 7 1 3 . 5 4 7}$ \\
\hline Aprrox 2015 & 19 & 953.436 & 515.712 & 55 & 351.997 & 189.610 .714 .008 \\
\hline Jan' 2015 & 19 & 79.453 & 42.976 & 55 & $\mathbf{3 5 1 . 9 9 7}$ & $\mathbf{1 5 . 8 0 0 . 8 9 2 . 8 3 4}$ \\
\hline Pertumbuhan & $\mathbf{4}$ & $\mathbf{1 3 6 . 9 6 3}$ & $\mathbf{- 4 5 . 2 3 0}$ & $\mathbf{- 1 5}$ & $\mathbf{- 1 4 4 . 0 3 8}$ & $\mathbf{- 9 6 . 2 2 3 . 9 0 3 . 4 5 5}$ \\
\hline
\end{tabular}




\begin{tabular}{|c|c|c|c|c|c|}
\hline Analisis Korelasi & 0,90 & $-1,00$ & $-0,97$ & $-0,93$ & $-0,94$ \\
\hline \multicolumn{3}{|c|}{ Korelasi terhadap Penjualan Kamar } & 0,97 & 0,93 & 0,94 \\
\hline
\end{tabular}

b. Keterbatasan bandara dan moda transportasi.

c. Ketidakberimbangan supply dan demand perhotelan.

\subsection{Analisis Benchmark Desain Perkotaan Lokasi Pengembangan MICE}

Tabel 5. Benchmark Desain Perkotaan Pusat MICE (Hasil Analisis, 2014)

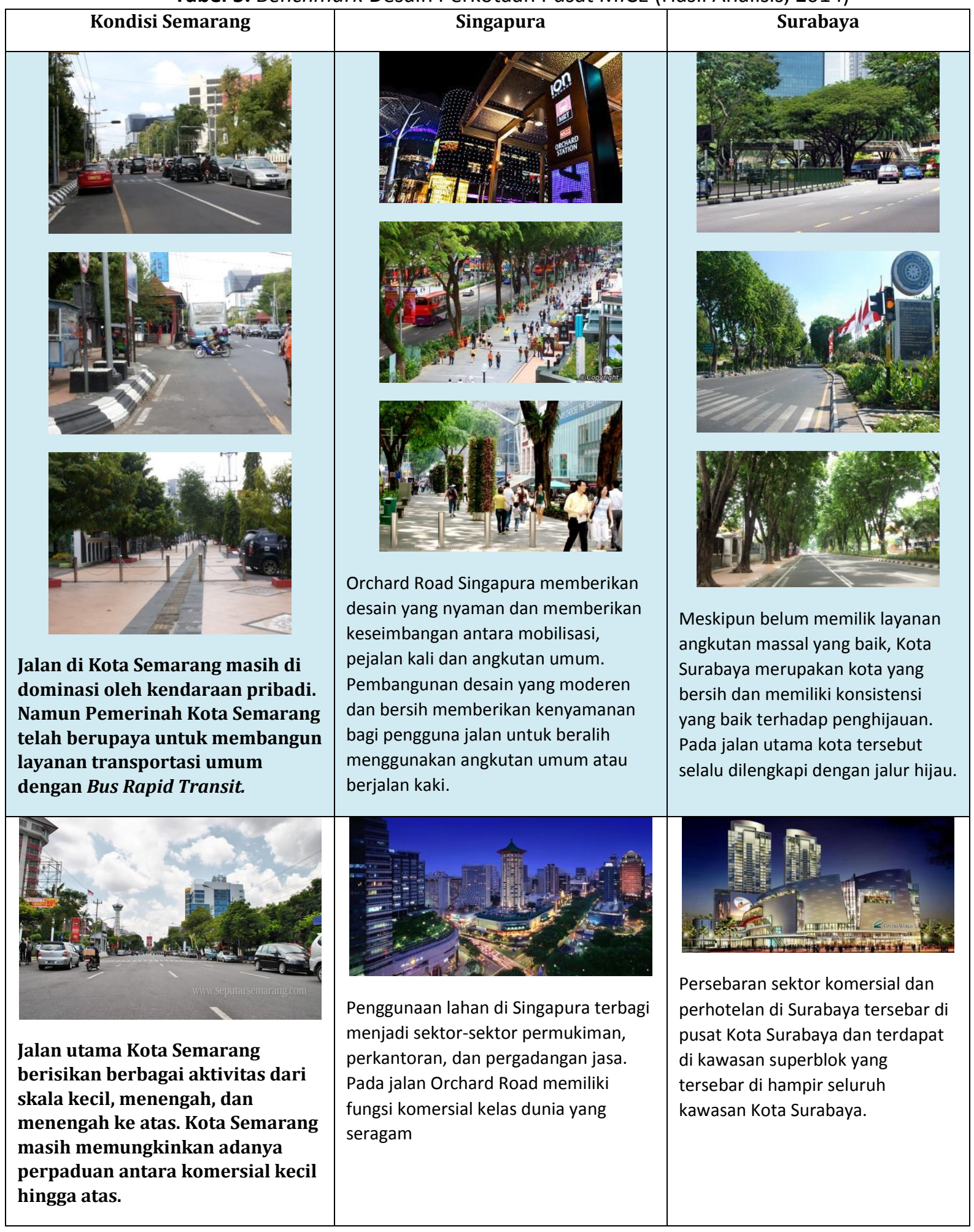




\section{KESIMPULAN}

Perhotelan perkotaan berbasis dagang dan bisnis memiliki perbedaan pada pengembangan perhotelan pada kawasan objek wisata konvensional. Perhotelan pada kawasan perkotaan didorong oleh aktivitas ekonomi bisnis, perdagangan, dan jasa pada kota tersebut atau yang bisa disebut sebagai kegiatan MICE (Meeting, Incentives, Conference, and Exhibition) yang tumbuh dan mengelompok pada pusat-pusat fasilitas dan layanan lainnya di pusat kota atau pusat kawasan. Pasar MICE Kota Semarang merupakan aspek potensial penyumbang pajak perhotelan hingga $70 \%$ dari total pendapatan pajak perhotelan Kota Semarang hingga tahun 2014. Perkembangan hotel pada kota bisnis membentuk pola pengembangan kota secara vertikal dan intensif ke dalam bagian perkotaan. Persebaran demand muncul pada pusat-pusat pelayanan kota seperti di sekitar Simpang Lima dan Kawasan Jalan Pemuda sebagai bentuk kegiatan MICE yang menginginkan mudahnya akses terhadap fasilitas penunjang lainnya. Berkembangnya kegiatan bisnis memicu tumbuhnya perhotelan sebagai sektor akomodasi dalam menampung kegiatan rapat dan meeting yang dilakukan oleh instansi pemerintah maupun swasta.

Adanya pelarangan kegiatan pegawai negeri untuk mengadakan kegiatan di hotel mengakibatkan adanya penurunan pendapatan pengguna hotel. Berkurangnya demand atas hotel ini jutru bersamaan dengan meningkatnya jumlah penyediaan hotel baru yang mengancam eksistensi hotel-hotel yang akan beroperasi di Kota Semarang maupun Kota MICE lainnya. Diperlukan kajian terhadap peningkatan kuota dalam kebijakan pro-invetasi yang baik untuk menjaga stabilitas kegiatan ekonomi yang telah berjalan sebelumnya agar peningkatan supply tidak mengganggu dinamika pasar yang terjadi saat ini. Penurunan penggunaan atas kamar hotel mengakibatkan adanya penurunan pendapatan dan penurunan pendapatan pajak hotel. Jika tidak segera dibenahi dengan meperlebar jalur demand maka prospek pengembangan perhotelan tidak akan berkembang dikemudian hari.

Upaya dalam mengembangkan dan menjaga eksistensi sektor MICE dalam perkotaan, pemerintah dan pelaku usaha perlu meningkatkan variasi layanan pada atraksi/daya tarik dan peningkatan layanan fasilitas dan infrastruktur. Diperlukan revitalisasi objek wisata kota baik secara alamiah, buatan, maupun wisata sejarah yang dikembangkan sebagai daya tarik kunjungan wisata dalam kota. Selain itu perkembangan perhotelan MICE pada kota bisnis juga sangat bergantung pada simpul transportasi nasional dan internasional sebagai pintu utama bisnis, perdagangan, dan jasa di kota tersebut. Di sisi lain, pelaku usaha perhotelan juga perlu memperhatikan permasalahan perhotelan pada aspek penyediaan parkir, penyediaan ruang terbuka hijau, dan pengolahan air limbah untuk menjaga kualitas lingkungan perkotaan.

Rekomendasi diberikan untuk peningkatan kualitas kawasan Petawangi dan sektor perhotelan di dalamnya. Rekomendasi dibagi menjadi dua bentuk yaitu rekomendasi kebijakan dan rekomendasi perencanaan.

\section{Rekomendasi Kebijakan}

Rekomendasi yang dapat diberikan kepada stakeholder terkait yang terkiat dalam pengembangan kawasan Petawangi dan sektor perhotelan di dalam kawasan tersebut antara lain:

a. Rekomendasi Pemerintah

Beberapa hal yang dapat dilakukan oleh pemerintah adalah:

i. Pengembangan transportasi bandar udara Kota Semarang

ii. Pembangunan objek wisata atau atraksi wisata baru di Kota Semarang

iii. Peningkatan kualitas infrastruktur perkotaan

iv. Penjagaan keamanan dan stabilitas politik di Kota Semarang

v. Pengkajian batas kuota pembangunan ijin perhotelan untuk menjaga dinamika pasar yang sehat

b. Rekomendasi Pelaku Usaha Perhotelan

Diperlukan strategi yang perlu dilakukan oleh pelaku usaha dalam menciptakan sektor perhotelan yang nyaman, aman dan ideal. Beberapa diantaranya berupa kebijakan dan pembenahan layanan dasar yang perlu ditingkatkan guna meningkatkan daya guna dan mengantisipasi permasalahan yang mungkin muncul akibat kegaiatn MICE di hotel antara lain:

i. Pembangunan ruang parkir yang memadahi. Ruang parkir dapat dilakukan secara masingmasing pengusaha hotel atau dengan gedung parkir komunal. 
ii. Penambahan fasilitas pengolahan limbah untuk menjaga kualitas lingkungan yang tidak semakin memburuk

iii. Penyediaan ruang terbuka hijau (RTH) sesuai dengan amanat UU Penataan Ruang yaitu $10 \%$ dari total luasan lahan. RTH konvensional dapat dialihkan dengan menggunakan roof garden

iv. Antisipasi sasaran MICE untuk menanggulangi dampak kerugian yang mungkin timbul

v. Komunikasi aktif dengan Pemerintah Kota Semarang melaui wadah PHRI untuk penanganan permasalahan yang mungkin timbul dikemudian hari.

2. Rekomendasi Perencanaan

Sebagai kawasan padat dengan penggunaan lahan dengan tingkat diferensiasi yang tinggi, diperlukan metode perencaan yang komprehensif dan menyeluruh untuk menjaga kerbelanjutan pembangunan melalui konsep pembangunan berkelanjutan pada konsep kota kompak atau compact city. Elkin (dalam Zhou, 2011) mengtakan bahwa kota kompak adalah kota yang terkonsetrasi, memiliki kepadatan yang tinggi dan memiliki penggunaan lahan campuran yang intensif dan berdiri secara mandiri. Hal ini sama yang terjadi dengan kawasan Petawangi yang memiliki kepadatan yang tinggi dan campuran penggunaan lahan. Untuk kondisi Petawangi, perencanaan yang dapat dikembangkan antara lain:

a. Manajemen transportasi yang terintegrasi dan melayani semua ruang jalan di dalam kawasan Petawangi.

b. Penyediaan layanan transportasi langsung dari Petawangi ke simpul transportasi seperti bandara, stasiun dan terminal

c. Pembangunan bangunan permukiman baru secara vertikal pada segmen kelas menengah dan kebawah.

d. Pembenahan sistem saluran dan penyediaan IPAL untuk menanggulangi degradasi lingkungan

e. Peningkatan kapasitas dan peran sosial terutama pada kampung-kampung kota yang eksistensinya terancam akibat perluasan lahan perdagangan dan jasa melalui regenarsi kawasan atau program KIP

Pembangunan gedung parkir terpadu di kelurahan dengan kepadatan aktivitas hotel dan komersial tinggi, terutama Sekayu, Pekunden, dan Karang Kidul.

\section{DAFTAR PUSTAKA}

BAPPEDA. (2004). Perda Kota Semarang Nomor 6 Tahun 2004. Badan Perencanaan Pembangunan Daerah Kota Sematang.

BPS. 2013 Kota Semarang dalam Angka 2013. Badan Pusat Statistik Kota Semarang.

Catanese, Anthony. J dan J. James. C. Snynder. (1986). Teori Perencanaan Kota. Jakarta. Penerbit :Erlangga. Drucker, Peter F. (2002). Management Challenges for the 21th Century. US: Perfect Bound.

Kotler, Philip, dkk. (2003). Marketing for Hospitality and Tourism. New Jersey: Prentice Hall.

Kotler, Philip, dkk. (1993). Marketing Places. New York: The Free Press.

Moleng, Lexy J. (2005). Metodologi Penelitian Kualitatif. Bandung: Rosda.

Porter,Michael E. (1990). The Competitive Advantage of Nation. New York: The Free Press.

Wardiyanta. (2006). Metode Penelitian Pariwisata. Yogyakarta: Penerbit ANDI.

Yunus, Hadi Sabari. (1982). Pengarahan Pemahaman Pengertian Kota. Yogyakarta: Fakultas Geografi,UGM .

Yunus, Hadi Sabari. (2005). Manajemen Kota: Perspektif Spasial. Yogyakarta: Pustaka Pelajar.

Yunus, Hadi Sabari. (2006). Megapolitan: Konsep, Problematika, dan Prospek. Yogyakarta: Pustaka Pelajar. 